Abstract 225 Table 1 Disease characteristics, treatment and outcome of 10 SLE patients with GI manifestations

\begin{tabular}{|c|c|c|c|}
\hline Age & Gastrointestinal manifestations or involvement & Treatment & Outcome \\
\hline 34 & Abdominal pain, nausea, vomiting, diarrhea & Dexamethasone & Improved \\
\hline 33 & $\begin{array}{l}\text { Recurrent abdominal pain, abdominal tenderness, atrophic } \\
\text { gastritis, appendicitis }\end{array}$ & $\begin{array}{l}\text { Methylprednisolone, } \\
\text { cyclophosphamide, explor } \\
\text { lap with appendectomy }\end{array}$ & Improved \\
\hline 45 & $\begin{array}{l}\text { Epigastric pain, abdominal tenderness, ileus with bowel } \\
\text { dilatation }\end{array}$ & Dexamethasone & Improved \\
\hline 49 & $\begin{array}{l}\text { Abdominal pain, diarrhea, hematochezia, ileus, "double } \\
\text { halo" sign by CT scan, rectal ulcers, necrotic rectosigmoid }\end{array}$ & $\begin{array}{l}\text { Hydrocortisone, } \\
\text { dexamethasone, } \\
\text { abdominoperineal with ileal } \\
\text { resection }\end{array}$ & Died \\
\hline 25 & Abdominal pain, vomiting, ileus & Hydrocortisone & Improved \\
\hline 33 & Abdominal pain, nausea, vomiting, ileus & Methylprednisolone & Improved \\
\hline 27 & Abdominal pain, diarrhea & $\begin{array}{l}\text { Hydrocortisone, } \\
\text { dexamethasone }\end{array}$ & Improved \\
\hline 19 & $\begin{array}{l}\text { Abdominal pain, vomiting, ileus, "double halo" and "comb" } \\
\text { sign by CT scan }\end{array}$ & Methylprednisolone & Improved \\
\hline 24 & $\begin{array}{l}\text { Abdominal pain, vomiting, diarrhea, mucosal inflammation, } \\
\text { pneumoperitoneum, by CT scan, ileal perforation }\end{array}$ & $\begin{array}{l}\text { Methylprednisolone, } \\
\text { belimumab, ileal resection }\end{array}$ & Improved \\
\hline 28 & $\begin{array}{l}\text { Abdominal pain, ileus, ascites, diffuse enterocolitis with } \\
\text { pancreatitis by CT scan }\end{array}$ & $\begin{array}{l}\text { Methylprednisolone, } \\
\text { cyclophosphamide }\end{array}$ & Improved \\
\hline
\end{tabular}

hypocomplementemia (60\%), alopecia (50\%), and hemolyticanemia (40\%). All patients showed significant initial response to high dose corticosteroid. Three patients eventually required surgery including ileal resection, abdomino-perineal resection and appendectomy; post-op histopath findings confirmed vasculitis in all 3 patients. One patient with ileal ischemia and perforation requiring resection also received belimumab infusions which enabled successful tapering and discontinuation of steroid. Another patient with refractory protein losing enteropathy and ischaemic colitis underwent abdomino-perineal with ileal resection, but succumbed to anastomotic failure with fulminant bacterial peritonitis.

Conclusions Though rare, gastrointestinal flare in SLE can be potentially catastrophic. Because of nonspecific manifestations, diagnosis strongly relies on clinical assumption and response to steroids. In some cases, surgery can be life-saving and belimumab offers another effective therapeutic option.

\section{RELAPSES OF LUPUS NEPHRITIS - RISK FACTORS, INCIDENCE AND IMPACT OF OUTCOME}

${ }^{1} \mathrm{D}$ Monova, ${ }^{2} \mathrm{~S}$ Monov*. 'Medical University - Sofia- Medical Institute, Department of Internal Diseases, Sofia, Bulgaria; ${ }^{2}$ Medical University - Sofia, Department of Internal Diseases- Clinic of Rheumatology, Sofia, Bulgaria

10.1136/lupus-2017-000215.226
Background and aims The aim of this study was to review renal flare frequency, to identify potential risk factors for relapses, to assess the value of serological tests during flares and to analyse their impact of global outcome in lupus nephritis (LN) patients.

Methods Patients with biopsy proven LN were identified from our database. LN classes were defined according to the ISN/ RPS classification. According to the response to treatment, LN patients were divided into 3 groups of complete remission (CR), partial remission (PR) and no response (NR). Those in remission were divided into 2 groups of relapsing and nonrelapsing during maintenance period.

Results $218(70,64 \%)$ of 276 SLE patients with biopsy proven LN (class I-18 patients, class II-45, class III-56, class IV-75, class V-54, class VI-2, mixed forms - 26) achieved either CR $(55,8 \%)$ or PR $(23,2 \%) .47$ patients had one flare, 36 - two, 27 - three, $17 \geq 4$ flares. The maintenance immunomodulating drugs at the time of flare was low dose corticosteroids and/or azathioprine. Non-adherence to treatment at time of relapse was documented in 26 patients.

Conclusions Renal flares in patients with LN are common, have a negative impact on outcome, but cannot be readily predicted. Our study shows that $58,83 \%$ of $\mathrm{LN}$ patients develop at least one relapse after reaching remission, usually within 2 years. The length of time to flare tends to be shorter in cases of preceding PR than in CR. Lack of adherence to long term immunosuppression was identified as a significant factor in LN flare $(20,47 \%)$. 
227 PREVALENCE OF NPSLE IN NORTH-INDIAN SLE PATIENTS AND ITS IMPACT ON QUALITY OF LIFE

${ }^{1} \mathrm{H}$ Muhammed*, ${ }^{2} \mathrm{~V}$ Lal, ${ }^{1} \mathrm{~V}$ Dhir, ${ }^{2} \mathrm{MK}$ Goyal. ${ }^{1} P G I M E R$, Internal Medicine, chandigarh, India; ${ }^{2} P G I M E R$, Neurology, chandigarh, India

\subsection{6/lupus-2017-000215.227}

Background and aims To look at the prevalence of neuropsychiatric manifestations in patients with SLE and assess its impact on qol
Methods We included consecutive patients with SLE above the age of 18 [(SLICC) 2012]. A diagnosis of an NP (neuropsychiatric) syndrome was made as per ACR 1999 definitions. Manifestations occurring at any point of time after the diagnosis of SLE were considered. Some modifications used were - headaches were included if $>4$ hours, mood disorders or anxiety was considered if the patient reported them to cause 'significant distress or impairment in functioning'. Cognitive testing was done by using the mini-mental state examination (cut-off of 23). Testing for autonomic neuropathy only involved blood pressure response to standing $(>=30 / 15$

Abstract 227 Table 1 Comparison of basic descriptors among patients with and without NPSLE

\begin{tabular}{|c|c|c|c|c|}
\hline & $\begin{array}{l}\text { All SLE patients } \\
\mathrm{n}=101\end{array}$ & $\begin{array}{l}\text { Patients with } \\
\text { NPSLE } \\
\mathrm{n}=33\end{array}$ & $\begin{array}{l}\text { Patients } \\
\text { without NPSLE } \\
\mathrm{n}=68\end{array}$ & $p$ value \\
\hline Age, years $\pm S D$ & $32.3 \pm 10.0$ & $31.9 \pm 9.9$ & $32.5 \pm 10.2$ & 0.780 \\
\hline $\begin{array}{l}\text { Duration, } \\
\text { years } \pm S D\end{array}$ & $4.6 \pm 4.5$ & $4.5 \pm 4.1$ & $4.7 \pm 4.8$ & 0.837 \\
\hline $\begin{array}{ll}\text { Age } & \text { at } \\
\text { diagnosis, } & \\
\text { years } \pm S D & \end{array}$ & $27.8 \pm 9.1$ & $27.5 \pm 8.7$ & $27.9 \pm 9.4$ & 0.837 \\
\hline Sex ratio $(\mathrm{M} / \mathrm{F})$ & $9 / 92$ & $1 / 32$ & $8 / 60$ & 0.148 \\
\hline $\begin{array}{l}\text { Serum } \\
\text { creatinine, } \\
\mathrm{mg} / \mathrm{dl} \pm \mathrm{SD}\end{array}$ & $1.23 \pm 0.71$ & $1.3 \pm 0.9$ & $1.2 \pm 0.6$ & 0.509 \\
\hline SLEDAI, \pm SD & $24.23 \pm 12.9$ & $31.1 \pm 15.5$ & $20.9 \pm 9.9$ & 0.001 \\
\hline $\begin{array}{l}\text { Hematological- } \\
\text { no(\%) }\end{array}$ & $81(80.2)$ & $24(72.7)$ & $57(83.8)$ & 0.189 \\
\hline $\begin{array}{l}\text { Malar rash- } \\
\text { no(\%) }\end{array}$ & $38(37.6)$ & $10(30.3)$ & $28(41.2)$ & 0.290 \\
\hline $\begin{array}{l}\text { Oral ulcer - } \\
\text { no(\%) }\end{array}$ & $36(35.6)$ & $12(36.3)$ & $24(35.2)$ & 0.925 \\
\hline $\begin{array}{l}\text { Nephritis } \\
\text { no }(\%)\end{array}$ & $57(56.4)$ & $15(45.5)$ & $42(61.8)$ & 0.121 \\
\hline ILD- no(\%) & $4(4.0)$ & $1(3.0)$ & $3(4.4)$ & 0.738 \\
\hline Carditis-no(\%) & $10(9.9)$ & $5(15.2)$ & $5(7.4)$ & 0.218 \\
\hline $\begin{array}{l}\text { Serositis- } \\
\text { no(\%) }\end{array}$ & $7(6.9)$ & $3(9.1)$ & $4(5.9)$ & 0.552 \\
\hline
\end{tabular}

